\title{
The Effectiveness of Labyrinth Game in Improving Interpersonal Intelligence of Children with Autism
}

\author{
Heavy Evasari \\ Department of Special Education, \\ State University of Malang, Indonesia \\ heavysari@gmail.com
}

\author{
Yuana Maulidia \\ Department of Special Education, \\ State University of Malang, Indonesia \\ yuana.maulidia@yahoo.com
}

\author{
Phylia Gita Crisantimum Chaerunnisa \\ Department of Special Education, \\ State University of Malang, Indonesia \\ ghylia.gita@gmail
}

\begin{abstract}
The purpose of this study is to improve interpersonal intelligence of children with autism: teamwork skill, interaction skill, comprehension, understanding and responding to a command. This research employs quasi experimental with Pretest-Posttest Control Group Design as the research design. The first chosen class is an experimental class treated by Labyrinth Box. The second class is a conventional class using Puzzle method and functions as a control. This control class, according to paired sample test, it shows no significant influence towards the improvement of interpersonal skill of children with autism. On the other hand, in the experimental class, it shows significant influence towards the improvement of interpersonal skill of children with autism. The comparison of the classes shows normal and homogeneous data. In addition, looking at independent sample test, it shows both classes own significant differences in improving interpersonal intelligence of children with autism. In the treatment of Labyrinth Box it shows the significant differences in improving interpersonal skill of children with autism.
\end{abstract}

Keywords: autism, interpersonal intelligent, labyrinth box

\section{INTRODUCTION}

Intelligence is abilities possessed by every individual to solve problem and learn from experience. Intelligence is one of the abilities owned by every individual that should be fully developed. One of the educational implementation emphasizes on physical growth and development, intelligence, social and emotional quotient, and language and communication. Intelligence has a great advantage for children and their social development. If children's intelligence develops well, they will be easier to catch lessons and socialize with their surroundings.

Various kinds of intelligences owned by each individual, according to Gardner that every individual has nine intelligences showing human's intelligence diversity, they are: (1) linguistic intelligence; (2) mathematic-logic intelligence; (3) spatial intelligence; (4) kinesthetic-physical intelligence; (5) musical intelligence; (6) interpersonal intelligence; (7) intrapersonal intelligence; (8) naturalistic intelligence; and (9) existential intelligence (Anggraeni, 2015). From these nine aforementioned intelligences, several intelligences are ruled out from academic intelligence by every individual. It is evident through several observations to schools; children's interpersonal intelligence has not developed well yet.

Interpersonal intelligence shows one's ability to be sensitive towards others' feelings, tend to understand, and interact with others so that they will be easy to socialize with their surrounding environment (Hamzah and Kudrat, 2009). Interpersonal intelligence is an inter-individual ability to understand others. It is an ability to understand others' moods, intentions, and desires and respond to it (Fariza, 2015). Thus, interpersonal intelligence is children's ability to understand others' intentions well, and interaction ability with their surroundings. Interpersonal intelligence has a pivotal role both in and outside learning. If a child has a good interpersonal intelligence, he/she will be easier to be sensitive during learning process.

Children are also asked to socialize during learning. This intelligence depends on individual interaction pattern; if an individual possesses a good interaction pattern, the interpersonal intelligence will be easier to develop. For those with special needs, interpersonal intelligence will be a primary need. It is commonly known that children with special needs characterized with their tendency to withdraw themselves as students with special needs in autism category.

\section{Research Design}

\section{METHODS}

This research is a quantitative approach. Quantitative research is a concentrate on symptoms that have certain characteristics in human life, called variables (Gunawan, 2016). The experimental research design applied in this study is quasi experimental with the research design pretest-posttest control group design. Two groups are chosen randomly. Those groups are divided into experimental and control groups.

In this design, the population is the lowest class of SDLB (elementary school for children with special needs). The first chosen class is the experimental class which is treated by giving Labyrinth Box game. The second class is the control class which studies without any treatment. After dividing the group, the next stage is pretest to know the early ability. Then, treatment is given to the experimental class. The treatment of control group is Puzzle game (daily media of autism). 
Table 1

Research Design

\begin{tabular}{lccc}
\hline \multicolumn{1}{c}{ Class } & Pre Test & Treatment & Post Test \\
\hline Expertimental & $\mathrm{O}_{1}$ & $\mathrm{X}$ & $\mathrm{O}_{2}$ \\
Control & $\mathrm{O}_{3}$ & - & $\mathrm{O}_{4}$ \\
\hline Notes: & & &
\end{tabular}

$\mathrm{O}_{1}$ : Pre test measurement in experimental class

$\mathrm{O}_{3}$ : Pre test measurement in control class

$\mathrm{O}_{2}$ : Post test measurement in experimental class

$\mathrm{O}_{4}$ : Post test measurement in control class

$\mathrm{X}$ : Treatment for experimental class by playing Labyrinth Box

\section{Data Collection}

\section{Research Preparation Stage}

Activities done in this stage are as follows: (1) studying the literatures related to the investigated problems; (2) determining the school which will be the object of this research; (3) getting in touch with the chosen school; (4) writing the permission letter for the research; (5) modifying Labyrinth Box game; (6) arranging the game syntax using Labyrinth Box; (7) initial observation; (8) determining the sample of the research; and (9) composing the research instrument.

\section{Research Implementation Stage}

The implementation of either Labyrinth Box or Puzzle game, to both experimental and control class, without implementing Labyrinth Box game, using observation sheets, syllabus, lesson plans and post-test (ability to control self and concentrate) as the technique of data collection in the form of behavior test.

\section{Final Stage}

The activities done this stage are as follows: (1) processing and analyzing data resulted by post-test; (2) discussing the result of the research; (3) drawing conclusions; and (4) giving suggestions and consulting the result of research data processing to the advisor.

\section{Data Analysis Technique}

The technique used in this study is the computation of rank correlation. This rank shows the influence degree of Labyrinth Box game in improving interpersonal intelligence of children with autism. In this analysis technique, it will shows whether the hypothesis is accepted or not, and $t$ can be seen that the value of correlation coefficient is high or low. The result of this analysis can be elaborated descriptively in order to be clearer. Below is this research hypothesis:

$\mathrm{H}_{\mathrm{a}}$ : A noticeable difference on the interpersonal intelligence of children with autism subsequent to treatment using Labyrinth Box compared to those using Puzzle

$\mathrm{H}_{\mathrm{o}}$ : No difference on the interpersonal intelligence of children with autism between those who treated by using Labyrinth Box and Puzzle

\section{Result AND Discussion}

Student score pretest and posttest on control class (puzzle) show in Table 2. In this research, a comparison is done between control (Puzzle) and experimental class (Labyrinth Box). In this comparison, prior to doing the test, normality test is firstly done to control class. This normality test uses Shapiro Wilk because the sample in this research is less than 50, precisely 6 students. In this test, the data is considered normal only if the significance value is more than 0.05 . This test results that the control class has pre-test significance value as 0.110 and for the post-test is 0.084 . Based on the data, it can be drawn that both pre-test and post-test data are normal.

To know the difference between pre-test and post-test, paired samples test is done. In this test, significance value is inversely proportional to the interpretation of significance value of normality test. This test is taken as influential in the significance value is less than 0.05 . On the data of control class, between pre-test and post-test reach the value of 0.102 . this value explains that there is no significant differences between pre-test and post-test in improving students' interpersonal intelligence. Student score pretest and posttest on Experimental Class (Labyrinth Box) show in Table 3.

Table 2

Data of Comparing Pre-Test and Post-Test on Control Class (Puzzle)

\begin{tabular}{cccccc}
\hline \multirow{2}{*}{ No } & \multirow{2}{*}{ Child } & \multicolumn{3}{c}{$\mathbf{O}_{\mathbf{3}}$} & \multicolumn{3}{c}{$\mathbf{O}_{\mathbf{4}}$} \\
\cline { 3 - 6 } & & Score & Mark & Score & Mark \\
\hline 1 & A & 13 & 32.5 & 14 & 35 \\
2 & B & 11 & 27.5 & 13 & 32.5 \\
3 & C & 10 & 25 & 13 & 32.5 \\
4 & D & 13 & 32.5 & 11 & 27.5 \\
5 & E & 10 & 25 & 14 & 35 \\
6 & F & 11 & 27.5 & 13 & 32.5 \\
\hline
\end{tabular}

Table 3

Data of Comparing Pre-test and Post-test on Experimental Class (Labyrinth Box)

\begin{tabular}{cccccc}
\hline \multirow{2}{*}{ No } & \multirow{2}{*}{ Child } & \multicolumn{2}{c}{$\mathbf{O}_{\mathbf{1}}$} & \multicolumn{2}{c}{$\mathbf{O}_{\mathbf{2}}$} \\
\cline { 3 - 6 } & & Score & Mark & Score & Mark \\
\hline 1 & A & 12 & 30 & 37 & 92.5 \\
2 & B & 10 & 25 & 20 & 50 \\
3 & C & 13 & 32.5 & 40 & 100 \\
4 & D & 12 & 30 & 32 & 80 \\
5 & E & 11 & 27.5 & 25 & 62.5 \\
6 & F & 11 & 27.5 & 34 & 85 \\
\hline
\end{tabular}


On the comparison between pre-test and posttest on experimental class (Labyrinth Box), normality test is also done firstly. The test used in this class is Shapiro Walk as well because of the same reason: the sample of this research is less than 50 , precisely 6 students. This test results that the experimental class (Labyrinth Box) has the significance value of pre-test as 0.820 and 0.739 for the post-test. From the data, it can be noted that both pre-test and post-test data of experimental class are considered normal because the significance value is more than 0.05 . To know the difference between pre-test and post-test, paired samples test is done. On the experimental class data (Labyrinth Box) reaches the value of 0.001 . This value explains that there is a significant difference between pre-test and post-test in improving interpersonal intelligence of children with autism since the significance value is less than 0.05 .

Table 4

\begin{tabular}{cccc}
\multicolumn{5}{c}{ Data of Comparing Control Class (Puzzle) } & and Experimental Class (Labyrinth Box) \\
\hline No & Child & $\mathbf{O}_{\mathbf{2}}$ & $\mathbf{O}_{\mathbf{4}}$ \\
\hline 1 & $\mathrm{~A}$ & 37 & 35 \\
2 & $\mathrm{~B}$ & 20 & 32.5 \\
3 & $\mathrm{C}$ & 40 & 32.5 \\
4 & $\mathrm{D}$ & 32 & 27.5 \\
5 & $\mathrm{E}$ & 25 & 35 \\
6 & $\mathrm{~F}$ & 34 & 32.5 \\
\hline
\end{tabular}

The next is comparing between control (Puzzle) and experimental class (Labyrinth Box). To know the difference of the influence of both classes, it should be done to meet several requirements. The first requirement is normality test. The data used is posttest data of both classes. Normality test used is still Shapiro Wilk because the sample of this research is less than 50, precisely 6 students. The difference of significance value can be notice on both classes: control class is 0.078 and experimental class is 0.739 . From the data, it can be concluded that the data of both classes are normal because the significance value in more than 0.05 .

The second requirement is homogeneity test. This test uses Lavene. In this test, the data is considered as homogeneous if the significance value is more than 0.05. Both classes reach 0.670. This explains that both control and experimental class have homogeneous data. The last is independent sample test that is done to know the difference of influence towards control and experimental class. Significance value is considered as influential is the value is less than 0.05. Control class reaches the value of 0.00 and 0.02 for the experimental class. Both data is less than 0.05 , it thus can be said that both classes have significant difference in improving interpersonal ability of children with autism.

Children with autism can be defined as those who like being in their own world. It can be seen as they prefer to communicate with themselves, dislike staring others, and tend to play with themselves. Therefore, children with autism often are called as children with their own world. Autism is a complex developmental disorder which is marked by interferences in interaction and communication ability, emotional, play and behavioral disturbances (Mudjito, 2015). These lacks differentiate children with autism with other common children. Yet, this condition cannot be developed.

Children with autism also can be defined as those who face difficulties in growing feeling as social empathy (Cristie, 2009). Hence, it is known then that one is considered suffered from autism if he/she has developmental disorder in three aspects: ability to interact socially and emotionally, the lack of qualified reciprocal communication ability, and limited interests together with repeated aimlessly moves. The impact of these obstacles cannot be seen as beneficial because these three challenges are the basic key to do activities with others, mainly in terms of cooperation. A child can cooperate if he/she can communicate well. Once they can communicate well, their behavior is appropriate with social norms. If those two matters can be done well, children's interaction with their surroundings can run well.

However, to do so, certain therapies are required to make children with autism are willing and can interact, especially in terms of cooperation. One of the alternatives to this problem based on above explanation is initiating a fun game as Labyrinth Box. Labyrinth is a place or road which is full of tortuous alleys, and learners will find its exit (Constantina, 2015). Labyrinth is a learning media which has several plots such as zig zag, small waves, and other plots. Haque and Rohani states in their research about APE maze or labyrinth is a mean that has several forms in order that the players can find the place by searching for the track and leaving scratches (Graficha and Endah, 2016). Labyrinth is an educational building through challenges game, principally introducing the nuance of adventure through a number of challenges by moving actively (Ulfa, 2011).

Maria (2011) says that labyrinth game can improve children's self-confidence with the following game's rules, several colorful flags designed with amazing pictures are put in a big labyrinth. Children go into the labyrinth and looking for the attached flags in several spot inside the labyrinth, then children take the flags and a command is written on the flag that should be done by the children. Constantina (2015) says that labyrinth game (maze) is a modified game one which only consists of a labyrinth in the form of numbers, and in the game, students are asked to follow the line of labyrinth picture in the form of numbers in books. 
Looking at the previous research results, the writer initiatively modifies labyrinth game to be Labyrinth Box, as a tool that can help children with autism to improve their interpersonal abilities: cooperation, interaction, understanding and responding to a command. Moreover, for hyperactive children with autism, this can be a medium to express their kinesthetic intelligence appropriately in the form of agility. The purpose of this study is to improve the interpersonal intelligence of children with autism: the ability to cooperate, interact, understand and respond to a command.

\section{Conclusion}

Two conclusions can be drawn in this study. First, modifying Labyrinth Box which is appropriate to the most to children with autism is the complicated one. Second, Labyrinth Box game has distinct influence compared to conventional media (Puzzle) in improving interpersonal intelligence. On Labyrinth Box game, a significant difference on interpersonal intelligence of children with autism is found.

\section{REFERENCES}

[1] Christie, P., Newson, E., Prevezer, W., \& Candler, S. 2009. Langkah Awal Berinteraksi dengan Anak Autis. Jakarta: PT. Gramedia Pustaka Utama.

[2] Constantina, E. L., \& Hasibuan, R. 2015. Pengaruh Permainan Maze Angka terhadap Kemampuan Mengenal Lambang Bilangan 1-10 Pada Anak Kelompok A. Retrieved June 7, 2017, from ejournal.unesa.ac.id.

[3] Gunawan, I. 2016. Metode Penelitian Kuantitatif. Retrieved June 7, 2017, from http://fip.um.ac.id/wpcontent/uploads/2015/12/2_Metpen-Kuantitatif.pdf.

[4] Kusuma, G. A. 2016. Pengembangan Permainan Labirin untuk Membantu Perkembangan Motorik Anak. PROtek, 3(2), 63-67. Retrieved June 7, 2017, from ejournal.unkhair.ac.id.

[5] Maria. 2011. The Effectiveness of Labyrinth Game in Building Children's Self-Confidence in Aisiyah Bustanul Athfal Kindegarten 2 Gadung Surabaya. Thesis. Surabaya: State University of Surabaya.

[6] Melda, N. F. 2016. Kecakapan Sosial Tunagrahita Ringan Kelas Dasar V di SLB Negeri 2 Yogyakarta. Widia Ortodidaktik, 5(1), 33-39. Retrieved June 7, 2017, from ejournal.student.uny.ac.id.

[7] Mudjito, A. K., Praptono, \& Jiehad, A. 2015. Pendidikan Anak Autis. Bandung: Djembatan.

[8] Sirait, R. B. 2013. Perancangan Aplikasi Game Labirin dengan Menggunakan Algoritma Backtracking. Jurnal Jurusan Teknik Informatika, Retrieved June 7, 2017, from http://www.academia.edu/donwload/37662537/21.rina sitrait.pdf.

[9] Ulfa, C. M. 2011. Efektifitas Labirin Game dalam Membangun Percaya Diri Anak di Taman Kanakkanak Aisiyah Bustanul Athfal 2 Gadung Surabaya. Dissertation. Surabaya: UIN Sunan Ampel Surabaya. Retrieved June 7, 2017, from digilib.uinsby.ac.id/9310/.

[10] Uno, B. H., \& Umar, K. M. 2009. Mengelola Kecerdasan dalam Pembelajaran. Jakarta: Bumi Aksara. 